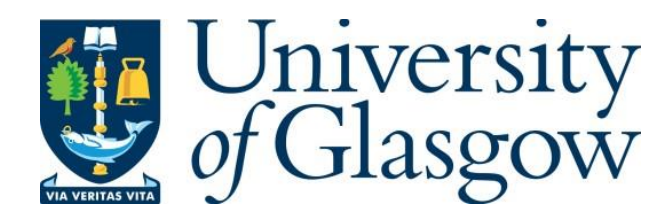

Steel, C. (2017) Defining public speech in the Roman Republic: occasion, audience and purpose. In: Rosillo-López, C. (ed.) Political Communication in the Roman World: Transmission and Exchange. Series: Impact of Empire (27). Brill: Leiden, pp. 17-33. ISBN 9789004350830

There may be differences between this version and the published version. You are advised to consult the publisher's version if you wish to cite from it.

http://eprints.gla.ac.uk/117971/

Deposited on: 26 May 2017

Enlighten - Research publications by members of the University of Glasgow http://eprints.gla.ac.uk 


\title{
Defining public speech in the Roman Republic: occasion, audience and purpose
}

\author{
Catherine Steel, University of Glasgow
}

The importance of public speech as a form of political communication and a means to political action in the Roman Republic is widely acknowledged. ${ }^{1}$ The role of the citizen body in determining policy through voting on legislative proposals combined with public speech as the key medium for disseminating information and debate ahead of voting ensured that oratory played a prominent role in political life. ${ }^{2}$ However, the definition of 'public speech' itself has received relatively little attention in these discussions, whose focus is generally on formal speeches whose purpose and format is defined by audience, context and aim. These speeches reflect the divisions of ancient rhetorical theory through which its practitioners were instructed: forensic speeches, particularly those delivered at trials held in the iudicia publica; deliberative speeches to the people and to soldiers, at contiones, and to the Senate; and, to a modest extent, largely involving speeches delivered at funerals, epideictic oratory.

However, to restrict the definition of 'public speech' to these formal categories of oratory distorts our understanding of the role of public speech in political life in the Republic because it leaves out many interactions which involved the public oral exchange of views but which did not take the form of oratio perpetua. These gaps are in large part a direct result of the nature of the source material, the written speeches which survive from the Republican period. The difficulties which arise from the fact that complete texts of speeches survive from only one speaker, Cicero, and that the fragments of speeches that survive from his predecessors and contemporaries are few in number and short length, are well-known. But dependence on Cicero is not the only problem in this particular case. Written speeches were a simplifying device: they were highly selective in terms of the kinds of public speech they recorded,

\footnotetext{
${ }^{1}$ Millar, F., 'The political character of the classical Roman republic, 200-151 B.C.', JRS 74 (1984): 1-19; Millar, F., 'Politics, persuasion and the people before the Social War.', JRS 76 (1986): 1-11; Jehne, M., ed, Demokratie in Rom? Die Rolle des Volkes in der römischen Republik, (Stuttgart: Franz Steiner 1995); Hölkeskamp, K.-J., Senatus populusque romanus: die politische Kultur der Republik. Dimensionen und Deutungen. (Wiesbaden: Steiner, 2004); Connolly, J., The State of Speech: Rhetoric and Political Thought in Ancient Rome, (Princeton: Princeton University Press 2007); Hölkeskamp, K.-J., Reconstructing the Roman Republic. (Princeton: Princeton University Press 2010).

${ }^{2}$ Millar, F., The Crowd in Rome in the late Republic, (Ann Arbor: University of Michigan Press 1998); Mouritsen, H., Plebs and politics in the late Roman Republic. (Cambridge: Cambridge University Press 2001); Morstein-Marx, R., Mass Oratory and political power in the late Roman Republic, (Cambridge: Cambridge University Press 2004); Steel, C., and van der Blom, H., eds, Community and Communication: oratory and politics in Republican Rome, (Oxford: Oxford University Press 2012).
} 
privileging the single speaker and uninterrupted speech, and imposed considerable editorial shaping on the texts themselves. In short, the oratio perpetua of written Roman oratory offers only a partial glimpse of the oral political culture of the Republic, and would do so even if the complete corpora of the speeches of Cato, Gaius Gracchus, Licinius Calvus and the other orators whose texts circulated alongside those of Cicero in the late Republican and early imperial periods had survived. This paper starts by exploring the differences between the picture of public speech presented in Cicero's oratorical texts and what we may hypothesise actually took place, in terms of the format of speaking. It then turns to the kinds of public speech which were not recorded through the medium of oratorical texts: cross-examinations in the Senate and in front of the people, the meetings of a politician's consilium, and exchanges which took place outside formally defined meetings. These other venues and occasions required oratorical skill and technique and were politically significant: they need to be considered alongside formal oratio perpetua in analysing the role of public speech at Rome.

\section{The representation of reality in the texts of oratory}

The extent to which Cicero altered the words that he had said when he came to disseminate a written version of speech has been the subject of intense and inconclusive debate. ${ }^{3}$ Much of this debate has focussed on the arguments and attitudes which the speeches display and the possibility that these aspects reflect a degree of hindsight. ${ }^{4}$ However, the broader question of the format of written oratory also requires attention. ${ }^{5}$ Cicero's speeches - and, as far as we know, those of his predecessors and contemporaries which also circulated in written form offer continuous, unbroken texts of considerable length which acknowledge the audience's existence but do not engage reciprocally with it. There is some variation within this model, particularly around length, which appears to correlate with rhetorical genre: some of Cicero's

\footnotetext{
${ }^{3}$ Alexander, M.C., The Case for the Prosecution in the Ciceronian Era, (Ann Arbor: University of Michigan Press 2002) offers (15-26) a comprehensive summary.

${ }^{4}$ Berry, D.H., 'The publication of Cicero's pro Roscio Amerino', Mnemosyne 57.1 (2004) 80-87.

${ }^{5}$ Fuhrmann, M., 'Mündlichkeit und fiktive Mundlichkeit in den von Cicero veröffentlichen Reden', in VogtSpira, G., ed., Strukturen der mündlichkeiten in der römischen Literatur (Tübingen: Narr 1990), 53-62; David, J.-M., 1999, 'Les procès-verbaux des judicia publica de la fin de la République romaine', in Khoury, R., ed., Urkunden und Urkundenformulare im Kalssischen Altetum und in den orientalischen Kulturen (Heidelberg: Winter 1999), 113-125.
} 
deliberative speeches are extremely short, whereas none of his forensic ones are. ${ }^{6}$ Yet despite these variations in length, all the written speeches which survive support a model in which the Roman orator spoke uninterruptedly and did so in a context which provided a clear generic definition, and consequently audience expectation, for his or her words.

The impression of unbroken and uninterrupted speech which Cicero creates, and which was also created by the texts which circulated from other orators, is unlikely be entirely accurate: there are good reasons to conclude that public speech was much more prone to interruption and disjunction that this textual picture of independent and autonomous speakers indicates. The debate on the relationship between speech and text has focussed on a range of possible editorial interventions; one of particular interest here is the relationship between an advocate's words and the material, written and oral, he elicited from witnesses. ${ }^{7}$ An example from Cicero's defence of Cluentius in 66 B.C. indicates how the text as disseminated could allude to, whilst omitting, such information. When Cicero finally turned to the charges of poisoning against his client, one of the three incidents he discussed (166-168) was the sudden death of a man called Balbutius, who, the prosecution appears to have alleged, died after Oppianicus' wedding party at which he had drunk a glass of wine intended for Oppianicus himself. Cicero's brief discussion of this charge concentrates on the fact that Balbutius died not on the day of the wedding but after an illness lasting aliquot dies, rather than, as the prosecution claims, statim. He says that the dead man's father can confirm this point:

What is the evidence for this? The same man as is witness to his loss: his father. The father, I repeat, of that young man; a man whom fragile suspicion might, given his distress of mind, have made a witness against Aulus Cluentius yet who instead is rescuing him with his evidence; please read it out. And, if it is not too much trouble, please also briefly rise; bear the pain of this unavoidable description; I shall not dwell on it longer than I must, since you have done what befits an excellent man and prevented your grief from bringing disaster and false accusation against an innocent man. ${ }^{8}$

\footnotetext{
${ }^{6}$ So, for example, reports to the people of debates held in the Senate, such as the fourth Catilinarian and fourth Philippic, tend to relative brevity.

${ }^{7}$ A number of Cicero's speeches contain headings which suggest that the written text has omitted some arguments (Font. 20; Mur. 57; Cael. 19) but these do not necessarily refer to witness evidence rather than an expanded argument which Cicero offered in court but elected to omit when disseminating the text.

${ }^{8}$ Cic. Clu. 168, quis huic rei testis est? idem, qui sui luctus, pater: pater, inquam, illius adulescentis: quem propter animi dolorem pertenuis suspicio potuisset ex illo loco testem in A. Cluentium constituere, is hunc suo
} 
There was a written statement from Balbutius senior about his son's illness and death, which, Cicero implies, was read out at this point in his speech; and Balbutius was present in court and available to give his evidence orally as well. At what point did he do so? Procedure in the iudicia publica indicates that the witness evidence was presented and witnesses crossexamined after the prosecution and defence had presented their cases. ${ }^{9}$ Yet Cicero's text here strongly suggests that he paused to allow Balbutius' evidence to be presented (which does not mean that Balbutius was not also summoned during the witness phase of the trial). ${ }^{10}$ If we accept that the texts of Cicero's speeches aim for verisimilitude, even if not necessarily verbatim accuracy, then this passage would indicate that the forensic orator could pause his own words to bring in another's voice in court itself, whilst preserving the illusion of a single speaker in the published version.

In addition to the interruption into advocates' speeches of witness evidence, whether written or spoken, it is evident that the cross-examination of witnesses was an integral element in most trials and required a distinct set of skills. This fluid and potentially unpredictable material was often extremely important in determining the outcome of a case, as shown not least by the radical changes which Pompeius introduced in 52 in terms of how such evidence was to be handled during trials. Under his new procedure, witness evidence was heard first; only after it had been heard, and the witnesses cross-examined, did the advocates have the opportunity to present their cases, and the time which they had was also curtailed. ${ }^{11}$ Yet we get little sense of the handling of witnesses from the surviving oratorical corpus. In Vatinium is a novel and, within the Ciceronian corpus, unique attempt to capture and preserve a cross-

\footnotetext{
testimonio sublevat; quod recita. tu autem, nisi molestum est, paulisper exsurge: perfer hunc dolorem commemorationis necessariae: in qua ego diutius non morabor, quoniam, quod fuit viri optimi, fecisti, ut ne cui innocenti maeror tuus calamitatem et falsum crimen adferret.

${ }^{9}$ Greenidge, A.H.J., The legal procedure of Cicero's Time, (Oxford: Clarendon Press 1901) 477-495; Santalucia, B., Diritto e processo penale nell'antica Roma, $2^{\text {nd }}$ ed., (Milan: Giuffrè 1998): 172-178; Lintott, A., 'Legal Procedure in Cicero's Time', in Powell, J. and Paterson, J., eds., Cicero the Advocate, (Oxford: Oxford University Press 2004), 61-78; Guérin, C., La voix de la vérité: témoins et témoignage dans les tribunaux romains de Ier siècle av. J.-C. Paris: Les Belles Lettres 2015): 93-140.

${ }^{10}$ Similar examples can be found throughout the second hearing against Verres, involving written evidence (Verr. 2.1.37, 57, 79, 83-4, 94, 96, 106, 128, 143, 150; 2.2.24, 183; 2.3.26, 45, 74, 83, 89, 100, 103, 123-4, 126, $154,168,175 ; 2.4 .12,53,143 ; 2.5 .54,62$ ); cf. also Clu. 148 (at which the transmitted text includes the words from the law which Cicero has asked to be read out); Flacc. 79; Sest. 10; Cael. 55. On Cicero's use of written evidence, Butler, S., The Hand of Cicero, (London: Routledge 2002).

${ }^{11}$ Asc. 36C; 39C; 53C; Lewis, R., Asconius: commentaries on speeches of Cicero. (Oxford: Oxford University Press 2006) ad loc.
} 
examination, but it still adopts the format of oratio perpetua. ${ }^{12}$ Trials in the iudicia publica involved a much wider range of activity than continuous speeches by advocates. ${ }^{13}$

The situation in relation to deliberative speeches was slightly different. Speech to the Senate or to the people could in theory take place without interruption. In practice, however, a degree of reciprocal exchange and consequent disruption to oratio perpetua appears to have been frequent, even universal. ${ }^{14}$ The Roman people expressed their views on what they heard at contiones in a variety of ways: vocal approval or disapproval, applause, gesture and ultimately the fact of their presence, or their choice to depart, were all ways in which audience communicated to speaker. A speaker was not compelled to respond to these demonstrations from his audience, but might choose to do so; and a speaker who failed to respond to his audience's wishes affected his chances of persuading them, and ultimately of continuing even to have an audience. Some instances of audience response might well be ones which a speaker had intended to elicit: as Morstein-Marx demonstrates, Cicero's contional speeches contain invitations to his audience to respond to what he had said in a particular way. ${ }^{15}$ An orator who chose to write up a contional speech for dissemination had to decide how to reflect in his speech its interaction with the audience: without breaking the illusion of a single continuous speech, the written version might include changes which recorded, in smoothed over form, moments at which the speaker responded to his audience's expressed views, as well as marking points at which the speaker paused in the expectation of a favourable response.

Oratory in the Senate took place within what was in some respects a highly structured framework of debate, particularly in terms of the order in which members were called to speak, the obligation on those called to express a view (though this could always consist simply of agreement with the position of an earlier speaker) and the amount of time available for discussion. ${ }^{16}$ In other respects, however, senatorial debate at Rome appears to have been fairly free; in particular, speakers seem to have been at liberty to diverge from the stated topic

\footnotetext{
12 On In Vatinium, Bensi, C., 'Su alcuni aspetti dell'In Vatinium di Cicerone' in Santalucia, B., ed, $L a$ repressione criminale nella Roma repubblicana fra norma e persuasione, (Pavia: IUSS 2009), 427-458; Guérin, La Voix, 148-154.

${ }^{13}$ Bablitz, L., Actors and Audience in the Roman Courtroom, (London: Routledge 2007); Hall, J., Cicero's Use of Judicial Theater, (Ann Arbor: University of Michigan Press 2014).

${ }^{14}$ Morstein-Marx, Mass Oratory, 119-159.

${ }^{15}$ Morstein-Marx, Mass Oratory, 136-143.

${ }^{16}$ Ryan, F., Rank and Participation in the Republican Senate, (Stuttgart: Steiner 1998); Lintott, A., The constitution of the Roman Republic, (Oxford: Oxford University Press 1999).
} 
of debate, and the filibuster was an established manoeuvre. The Senate could express its approval of speeches, though there is unfortunately relatively little evidence as to whether, and if so in what ways, a senatorial audience conveyed to a speaker a sense that he had gone on too long. Cicero's senatorial oratory tends to be much briefer than his speeches in other genres (apart from reports to the people of senatorial debates); it is also evident that he imposed a very high degree of selection in what he disseminated of his senatorial oratory in written form, which would be consistent with many of his senatorial contributions being short and unelaborated and as a result not considered viable candidates for dissemination in wirtten form. ${ }^{17}$ Even among his published senatorial speeches, it is possible that some amplification has taken place in the written version. A possible example is the speech De prouinciis consularibus. Although we need not doubt that Cicero made this unexpected statement of support for Caesar's ongoing military command in Gaul to the Senate in the early summer of 56 , and that it produced a considerable effect on its immediate audience, some elements of the speech, and particularly the invective against Piso and Gabinius, are perhaps less plausible in the context of oral delivery. Given what we know about Cicero's motives in contributing to this debate on the consular provinces, the written text was at least as important as the actual contribution to a senatorial debate leading up to a vote (at which Cicero's proposal was rejected), not least because a text could be dispatched to Caesar and to Pompeius; we can therefore reasonably suspect that conventions of textual dissemination, as well as Cicero's own ends, led to some degree of amplification.

\section{Alternatives to oratio perpetua}

Furthermore, uninterrupted speech by senators was not the only form of speech that took place in the Senate: direct and often hostile exchanges between senators were another format. In May 61 B.C., shortly after Clodius had been acquitted of the charge of sacrilege at the previous year's celebration of the Bona Dea, he and Cicero clashed in the Senate, and Cicero recorded their encounter in a letter to Atticus he wrote soon afterwards (Att. 1.16.10)

...that pretty little boy get up and accuses me of being at Baiae; not true, but anyway. 'Well? Is that like saying that I was somewhere hidden?' 'What has a man from

\footnotetext{
${ }^{17}$ See the material gathered in Crawford, J., M. Tullius Cicero: the Lost and Unpublished Orations, (Göttingen: Vandenhoeck and Ruprecht 1984).
} 
Arpinum to do with warm springs?'. 'Tell that', I said, 'to your counsel, who was keen on an Arpinum man's property at the springs' (you know about Marius' property.) 'How long', he said, 'shall we bear this king'? 'You appeal to a king, when Rex made no mention of you?' (he had been hoping to squander an inheritance from Rex). 'You bought a house'. 'You would think', I said, 'that he said, "He bought a jury"'. 'They didn't believe you on oath'. 'Oh twenty-five jurors did, but thirty-one gave you no credit at all - they took their fee up-front.'. Overwhelmed by a great roar he falls silent and collapses. ${ }^{18}$

Cicero is keen to emphasise the fact that he was triumphant in this exchange, a victory demonstrated through the response of his audience and the effect that this had on Clodius; we may wonder whether his victory was as pronounced as he makes out. But his account does seem to provide a good indication of the format of an altercatio in the Senate, with senators not speaking at length or without interruption, but engaged in exchange with one another, in a manner which was competitive and could involve considerable animosity. Technically, what seems to have happened was that Clodius sought and obtained from the presiding magistrate, the consul Pupius Piso (himself the object of attacks by Cicero in relation to the conduct of Clodius' trial), the opportunity to respond to the personal attacks which Cicero had directed at him during a speech he had given earlier at this particular meeting of the Senate. In his description of the meeting in this letter, Cicero draws an explicit distinction between oratio and altercatio. ${ }^{19}$ The altercatio he records with Clodius is political in its content; the outcome is of political significance, since it manifested the opinion of the Senate about the behaviour of two of its members, whether or not that opinion had been changed by what they had heard; and the skills required to be effective in this genre of oral communication are difficult to disentangle from the rest of the orator's rhetorical apparatus. ${ }^{20}$ To treat senatorial oratio

\footnotetext{
18 surgit pulchellus puer, obicit mihi me ad Baias fuisse; falsum sed tamen. 'quid? hoc simile est' inquam 'quasi in operto dicas fuisse?' 'quid' inquit 'homini Arpinati cum aquis calidis' 'narra 'inquam 'patroni tuo, qui Arpinatis aquas concupiuit'; nosti enim Marianas. 'quousque' inquit 'hunc regem feremus?' 'regem appellas' inquam 'cum Rex tui mentionem nullam fecerit?'; ille autem Regis hereditatem spe deuorarat. 'domum' inquit 'emisti.' 'putes' inquam 'dicere 'iudices emisti'. ' 'iuranti' inquit 'tibi non crediderunt.' 'mihi uero' inquam 'XXV iudices crediderunt, XXXI, quoniam nummos ante acceperunt, tibi nihil crediderunt.' magnis clamoribus adflictus conticuit et concidit.

${ }^{19}$ Cic. Att. 1.16.9-10, rogatus ego sententiam multa dixi de summa re publica...sed quid ago? paene orationem in epistulam inclusi. redeo ad altercationem (when asked my opinion I spoke at length about the res publica at the highest level...but what am I doing? I had practically included my speech in the letter. I return to the exchange).

${ }^{20}$ The amount of space that Cicero devotes to wit in De Oratore (2.216-290) is revealing in this context, given how many of the examples the speakers in the dialogue discuss concern not wit in oratio perpetua but in brief
} 
perpetua alone as 'oratory' and to deny membership of that category to altercatio is a counter-productive decision, driven by the conventions of oratory as a textual genre in Latin rather than the challenges and realities of political life.

A similar argument can be constructed about speech at the contio. As was discussed above, Cicero's contional speeches give the impression that the orator was heard in attentive silence broken only by approving murmurs or shouts at moments carefully orchestrated by the speaker himself. In fact, an address to a contio could involve hostile reactions from the crowd or even loss of audience. ${ }^{21}$ Moreover, these speeches of Cicero preserve only one format for the contio, but a contio could involve cross-examination as well as continuous speeches. Such cross-examination could itself vary considerably in tone. In the run-up to Milo's trial in 52, his opponents used contiones to make public material which was prejudicial to Milo's case; thus the tribune T. Munatius Plancus brought to a contio one M. Aemilius Philemon, who said that he had been kidnapped and imprisoned by Milo because they were witnesses to Clodius' murder:

Then Titus Munatius Plancus, tribune of the plebs, brought forward at a contio Marcus Aemilius Philemon, a well-known man and a freedman of Marcus Lepidus. He said that he and four other free men had come upon Clodius's murder as they had been travelling and, when they raised the alarm, they were snatched, taken away and kept shut up for two months in a villa of Milo's; whether true or false, the matter created a great deal of ill-feeling against Milo. ${ }^{22}$

It is not entirely clear how this information was conveyed at the contio: that is, whether Plancus elicited the information from Philemon through a series of questions or if Philemon,

exchanges between two or more speakers, whether in forensic, deliberative or more unstructured contexts; see further below.

${ }^{21}$ On hostile audiences at the contio, see Pina Polo, F., Contra arma verbis: der Redner vor dem Volk in der späten römischen Republik, (Stuttgart: Steiner 1996) 94-126; Aldrete, G., Gestures and Acclamations in Ancient Rome, (Baltimore: Johns Hopkins University Press 1999), 101-104. Cicero records (Brut. 305) the elder Curio's experience as tribune of the plebs, when he did not address contiones after he had once been abandoned by his contional audience; unfortunately Cicero does not explain what Curio had done to lose his audience. On Curio, see further Rosillo Lopez, C., 2012, 'The Common (mediocris) Orator of the Late Republic: the Scribonii Curiones', in Steel, C., and van der Blom, H., eds, Community and Communication: oratory and politics in Republican Rome, (Oxford: Oxford University Press 2012) 287-298.

22 Asc. 37C, deinde Titus Munatius tribunus plebis produxerat in contionem M. Aemilium Philemonem, notum hominem, libertum M. Lepidi. is se dicebat pariterque secum quattuor liberos homines iter facientes superuenisse cum Clodius occideretur, et ob id cum proclamassent, abreptos et perductos per duos menses in uilla Milonis praeclusos fuisse; eaque res seu uera seu falsa magnam inuidiam Miloni contraxerat. 
once introduced, described his experiences without interruption. However, Plancus, who summoned this meeting was, together with his tribunician colleagues Sallust and Q. Pompeius, consistently hostile towards Milo after Clodius' death, and it appears that this meeting's purpose, as well as its outcome, was to stir up inuidia against Milo. Consequently, it seems reasonable to assume that Plancus at the very least spoke before and after Philemon's account in order to show his audience exactly how they should respond to what they heard; and cross-examination is perhaps more likely than a longer speech by Philemon, to ensure that a speaker who was not familiar with oratory at the contio did bring out all the information that Plancus required.

In this particular episode the speakers, that is Plancus and Philemon, were on the same side; we should assume that Philemon came to the meeting having been carefully prepared and that what he said was what Plancus was expecting and hoping to hear. Hostile cross-examination was also possible. In such cases, the participants were normally both politically active; the context was often in the run-up to legislative voting, where one side might summon the other to explain their opposition (or support). One famous example was Carbo's cross-examination of Scipio Africanus after the death of Tiberius Gracchus, during which Scipio said that he thought that Gracchus had been justly killed, to an outraged response from the audience. (He then dismissed the audience's claim to any political role by saying that Italy was only a stepmother to them, and that they had been prisoners-of-war whom he himself had brought to Rome) ${ }^{23}$ That dynamic of open contempt is difficult to parallel; most speakers who found themselves the object of a hostile cross-examination at a contio faced, as Morstein-Marx puts it (2004: 166), 'a hard choice: either to back away publicly from his stance of opposition, or face a fearful, even potentially violent, explosion of popular anger, and court the imputation that he despised the Will of the People'. Such an environment demanded rhetorical competence, even though this competence would be displayed in brief responses rather than full-scale contional oratio perpetua.

\section{Informal speech beyond Senate and contio}

These examples involve well-defined locations for political activity, namely the Senate and the contio. Speech at those locations was not confined to longer, continuous and

${ }^{23}$ Val. Max. 6.2.3; cf. Cic. De Orat. 2.106; Vell. HR. 2.4.4. 
uninterrupted speech; the format of Senate meetings and meetings of the people allowed for briefer exchanges, which had political significance and demanded rhetorical skill, even though they did not fit with the conventions that emerged around written texts. I conclude with two more kinds of speech which test the boundaries of definitions of 'oratory' more severely because they did not take place within the formal frameworks offered by meetings of Senate and people.

The first of these kinds of speech is that which could take place at the consilium, a magistrate's advisory council. ${ }^{24}$ A consilium sat between formal and informal; there were no fixed rules governing its composition and conduct and yet its members and behaviour was the object of public scrutiny, as its role in repetundae trials makes clear. A meeting of a consilium could involve oratio perpetua, as is evident from a description that Cicero gives of a meeting of Brutus' consilium in the spring of 44 B.C.:

I reached Antium before midday. Brutus was glad to see me. Then in front of a large group, including Servilia, Tertulla and Porcia, he asked me my views. Favonius also was there. I presented what I had prepared en route: that he should take the Asiatic corn commission; our only concern now was his safety; in that lay also the security of the res publica itself. When I was launched on this speech Cassius walked in. I started it again. At this point Cassius with stern expression (he was breathing fire) said he would not go to Sicily. "Should I take an insult as though it were a favour?" "Well, what are you going to do?" I asked. He said he would go to Achaea. "What about you, Brutus" I asked. "To Rome, if you approve." "Not at all; you won’t be safe". "Well, would you agree if I could be?" "I would, and be against your going to a province now or after your praetorship; but I can't advise you to trust yourself to Rome". I gave him the considerations which of course occur to you as to why he would not be safe. Then there were great complaints, above all from Cassius, and they were very critical of Decimus and lost opportunities. I replied that there was no point in lamenting the

\footnotetext{
${ }^{24}$ A consilium was not the exclusive prerogative of a magistrate; any adult male Roman could ask his friends and family for advice and appears to have been expected to do so in the case of weighty decisions with consequences more than merely personal. However, the evidence for speech at meetings of consilia relates to those called by magistrates. On consilia more generally, Amarelli, F. Consilia principum, (Naples: Jovene 1983); Crook, J., Consilium Principis: imperial councils and counsellors from Augustus to Diocletian, (Cambridge: Cambridge University Press 1995); Johnston, P., The military consilium in Republican Rome (Piscataway: Gorgias Press 2008).
} 
past, but nonetheless I agreed. When I had begun to say what should have been done nothing startling, just what everyone is constantly saying - not making the point that someone else should have also been dealt with, simply saying that the senate should have been summoned, popular feeling stirred up more vigorously, leadership of the whole res publica assumed, your friend interrupted, "I have never heard anyone say so!". I held my tongue... ${ }^{25}$

Cicero expected to be asked to address this gathering, and had prepared some material on his journey to it. The role of preparation in what he said supports the idea that the consilium was potentially a setting for formal speech. But proceedings at this particular meeting were disorderly: Cicero's attempt to speak at some length was interrupted, first by the arrival of Cassius as Cicero was speaking, which led to some question and answer between the two men, followed by more general discussion, and then secondly by Servilia, who firmly expressed scepticism of Cicero's position. ${ }^{26}$ The meeting was not public: participation was by invitation only and there was no formal mechanism for its decisions to become known, insofar as it did indeed reach any decisions. But (as this letter makes abundantly clear) what happened at the meeting of a consilium could be of interest to those who had not attended it and could be leaked. Consequently, what was said in such an environment could have broader significance.

The second kind of speech is in many ways the converse: if consilia give us private but structured oratory, oratio perpetua that could be carefully planned even though its audience was restricted, a variety of unplanned, unscripted encounters in the public spaces of the city

\footnotetext{
${ }^{25}$ Cic. Att. 15.11.1-2, Antium ueni ante H. VI. Bruto iucundus noster aduentus. deinde multis audientibus, Seruilia, Tertulla, Porcia, quaerere quid placeret. aderat etiam Fauonius. ego, quod eram meditatus in uia, suadere ut uteretur Asiatica curatione frumenti; nihil esse iam reliqui quod ageremus nisi ut saluus esset; in eo etiam ipsi rei publicae esse praesidium. quam orationem cum ingressus essem, Cassius interuenit. ego eadem illa repetiui. hoc loco fortibus sane oculis Cassius (Martem spirare diceres) se in Siciliam non iturum. "egone ut beneficium accepissem contumeliam?" "quid ergo agis?" inquam. at ille in Achaiam se iturum. "quid tu" inquam, "Brute?" "Romam" inquit, "si tibi uidetur." "mihi uero minime; tuto enim non eris." "quid? si possem esse, placeretne?" " atque ut omnino neque nunc neque ex praetura in prouinciam ires; sed auctor non sum ut te urbi committas." dicebam ea quae tibi profecto in mentem ueniunt cur non esset tuto futurus. multo inded sermone querebantur, atque id quidem Cassius maxime, amissas occasiones Decimumque grauiter accusabant. 〈ad〉 ea negabam oportere praeterita, adsentiebar tamen. cumque ingressus essem dicere quid oportuisset, nec uero quicquam noui sed ea quae cotidie omnes, nec tamen illum locum attingerem, quemquam praeterea oportuisse tangi, sed senatum uocare, populum ardentem studio uehementius incitare, totam suscipere rem publicam, exclamat tua familiaris "hoc uero neminem umquam audiui!" ego repressi... ${ }^{26}$ On this meeting, see further Flower, H., 'Servilia's consilium: rhetoric and politics in a family setting', in van der Blom, H., Gray, C., and Steel, C., eds, Institutions and Ideology in Republican Rome: speech, audience and decision, forthcoming.
} 
of Rome, particularly the Forum, involved speech which was public but did not take the form of long addresses. The major source both for the nature of this kind of speech and for its significance is Cicero, and particulary the excursus on wit in the second book of De Oratore, during which Caesar Strabo draws on exchanges between politicians and private members of the populus to indicate how a member of the elite should and could use wit effectively. ${ }^{27}$ Two examples can show the potential significance of such kinds of speech. The first, from $D e$ Oratore, records a brief exchange between the orator Antonius (one of the interlocutors in the dialogue, as Strabo's telling indicates) and Helvius Mancia:

This is a rather trivial and, as I said, mime-like humour, but it has its place sometimes even in our work, as when someone who isn't stupid says, as though he were stupid, something witty: as Mancia did to you, Antonius, when he heard that you, as censor, were being prosecuted for electoral bribery by Marcus Duronius: "Now you'll mind your own business". ${ }^{28}$

Strabo's, and Cicero's, main point here is the humorous effect of the pun on negotium agere, with Mancia's simultaneous suggestions that the prosecution Antonius faces will compel him to attend to his own affairs (the meaning which is quasi stulte, presumably because it is so banal) whilst also indicating that there will be general relief if Antonius as censor stops interfering in other people's business. ${ }^{29}$ The anecdote does not, therefore, include any information about where the encounter took place or how other people came to know about it. But the inference can reasonably be drawn that Mancia and Antonius encountered one another in some public space in Rome and that other people heard what they said to one another. The difference in status between the two men is notable: Antonius, former consul and current censor, and Mancia, the son of a freedman. ${ }^{30}$ The second example also involves an exchange between a senator and a non-senator:

\footnotetext{
${ }^{27}$ See above, n. 19.

${ }^{28}$ Cic. De Orat. 2.274, genus hoc leuius et, ut dixi, mimicum, sed habet non numquam aliquid etiam apud nos loci, ut uel non stultus quasi stulte cum sale dicat aliquid: ut tibi, Antoni, Mancia, cum audisset te censorem a M. Duronio de ambitu postulatum, aliquando inquit tibi tuum negotium agere licebit.

${ }^{29}$ Leeman, A., Pinkster, H., and Rabbie, E., Tullius Cicero De Oratore Libri III: Kommentar, dritte Band: Buch II, 99-290, (Heidelberg: Winter 1989) 311.

${ }^{30}$ On Mancia, see further Steel, C., 'Pompeius, Helvius Mancia and the Politics of Public Debate', in Steel, C., and van der Blom, H., eds, Community and Communication: oratory and politics in Republican Rome, (Oxford: Oxford University Press 2012), 151-159.
} 
Likewise when Marcus Drusus, tribune of the plebs, a very powerful man one engaged in great political struggles, greeted Granius and said, as one does, "How are you doing, Granius?”, Granius responded, “No rather, how are you, Drusus, doing?”31

As in the first example, the actual exchange depends on a phrase's double meaning, where the conventional greeting quid agis is unpacked by its recipient Granius into a pointed enquiry about the activities which Drusus is up to as tribune. Again, location is not specified, but as in the case of Antonius and Mancia, the story's very existence implies listeners.

This second anecdote comes from Cicero's speech for Plancius, at a point at which Cicero is attempting to refute an allegation that Plancius speaks with excessive frankness by listing occasions on which Roman grandees have faced rough verbal treatment from those of lesser social status. Both Livius Drusus and Antonius are worsted in these stories: their social and political superiority is undermined by their lack of verbal facility in comparison with Mancia and Granius. Indeed, perhaps one of the reasons these anecdotes had value was in their reversal of the proprieties ('he said what!'). And it also seems that such encounters could matter - or at least were thought to have the potential to matter - to a politician's reputation. Hence the inclusion of such material in De Oratore: being a competent communicator in this type of exchange, or at the least being able to avoid very obvious pitfalls, was relevant to the politician and orator. Such conversations, involving men in public life in a public place, were liable to be remembered and passed round, at least in oral discussion. They did not involve any preparation (indeed, they seem to have been unexpected) and they did not have a formal context. But although there is a clear demarcation between them and the kinds of oratio perpetua which was recorded in writing and circulated, it is less easy to distinguish them, in terms at least of the kinds of speech used, from the oral exchanges which took place in the courts and Senate and in front of the people.

\section{Conclusions}

Oratorical texts from the Roman Republic cannot alone establish the parameters of public speech. These texts edit and simplify the circumstances of performance, conceal the role of

\footnotetext{
${ }^{31}$ Cic. Planc. 33, idem tribuno pl. potentissimo homini, M. Druso, et multa in re publica molienti, cum ille eum salutasset et, ut fit, dixisset: quid agis, Grani? respondit: immo uero tu, Druse, quid agis?
} 
the audience, and emphasise the authority and control of the speaker. Public speech must be addressed within the context of political life as a whole, and the result of so doing is to establish a spectrum of activity, ranging from, at one end, organised and disciplined occasions of elaborate public oratory, through increasingly interrupted and contested speech which nonetheless takes place at formally defined events to, at the other end, brief impromptu verbal exchanges in public but outside any institutional framework, whose transition into the public sphere was contingent and even fortuitous. But all have some claim to be considered 'public speech' and to contribute meaningfully to our understanding of political communication at Rome. ${ }^{32}$

\footnotetext{
${ }^{32}$ This paper is the product of research carried out as part of the European Research Council funded project The Fragments of the Republican Roman Orators. I am grateful to the editor for her invitation to participate in the conference which led to this volume and to participants in that conference and the readers of this volume for their constructive feedback.
} 